\title{
Changes in Perceptions and Attitudes of Medical Students toward End-of-Life Care after Hospice and Palliative Medicine Education
}

\author{
Jeehyun Cha, M.D., Hoseob Lihm, M.D., Ph.D., Yoonyoung Kim, M.D. and Jihun Kang, M.D., M.S. \\ Department of Family Medicine, Kosin University Gospel Hospital, Kosin University College of Medicine, Busan, Korea
}

Purpose: High-quality hospice and palliative medicine curricula are necessary in Korean medical schools. This study evaluated changes in students' knowledge and attitudes toward both hospice and palliative care following the completion of a course on these topics, as well as the course's overall role in the basic medical education curriculum. Methods: Questionnaires measuring knowledge and attitudes were collected before and after the course from 76 fourth-year medical students, who had received instructions integrating both hospice and palliative care in 2016. Results: The questionnaire item "Select the correct answer on the use of opioid pain control in hospice and palliative care" changed the most in terms of number of correct answers pre- and post-course (3.50 and 5.32, respectively; $\mathrm{P}<0.001$ ). Pre- and post-course, the numbers of students who answered "Strongly Agree" and "Agree" to questions concerning their attitudes toward hospice and palliative care ("I know the purposes and roles of hospice and palliative care") were 17 (22.4\%) and 65 (85.6\%), respectively ( $\mathrm{P} \leq 0.001)$. Affirmative responses also increased for "As a pre-physician, I know when to describe and advise hospice and palliative care to patients", from $22(28.9 \%)$ to 65 (85.6\%; $\mathrm{P} \leq 0.001$ ). Conclusion: This study showed that comprehensive hospice education in the form of an integrated educational course might promote changes in medical students' knowledge and attitudes toward hospice and palliative medicine.

Key Words: Hospice care, Palliative medicine, Perception, Attitude, Medical education
Received May 30, 2019

Revised September 9, 2019

Accepted October 24, 2019

\section{Correspondence to}

Jihun Kang

Department of Family Medicine, Kosin

University Gospel Hospital, Kosin

University College of Medicine, 262

Gamcheon-ro, Seo-gu, Busan 49267,

Korea

Tel: +82-51-990-6155

Fax: +82-51-990-3045

E-mail: josua85@naver.com

\section{INTRODUCTION}

Hospice care aims to increase patients' quality of life through comprehensive and continuous care, specifically for those predicted to die within six months (1). Although the need for medical training in hospice and palliative care has been emphasized worldwide, sufficient education in this field has yet to be achieved (2-5).

Since 2008, the United States (US) has implemented a hospice and palliative care curriculum within their medical schools.
According to George Dickinson's (2011) survey, US medical students participating in death and dying services increased from $71 \%$ in 1975 to $100 \%$ in 2010 (6).

The United Kingdom (UK) introduced hospice and palliative care courses in their medical schools' curricula with the release of the second edition of the General Medical Council's Tomorrow's Doctors publication; it became a required course with the release of the third edition (3). Following the UK's decision, many countries have since emphasized hospice and palliative care education. 
However, as hospice and palliative care education within Korea has specifically targeted nurses, many doctors and medical students lack sufficient knowledge in this area (7). In addition, although a hospice specialist curriculum was developed by the Korean Hospice and Palliative Care Society to be implemented nationally (8-10), physicians' participation rates in this program are suboptimal. Furthermore, a knowledge gap exists regarding the impact of hospice and palliative care education, particularly regarding medical students' attitudes toward end-of-life care. In this context, this study aimed to evaluate changes in students' knowledge and attitudes toward hospice and palliative care following completion of a relevant, integrated course, as well as to understand the role of this course in the basic medical education curriculum.

\section{METHODS}

\section{Study participants and data collection}

Seventy-six fourth-year medical students receiving integrated education in hospice and palliative medicine in 2016 were eligible for inclusion in this study. Participation was voluntary, and only participants who agreed to participate and completed the questionnaire were recruited. A total of 76 participants responded to the questionnaire, with a $100.0 \%$ response rate. Informed consent was obtained from all study participants.

The questionnaire was originally designed to identify students' attitudes toward hospice and palliative care as a part of a course satisfaction survey which evaluated attendees' unmet needs related to palliative care education. However, based on the notion that the questionnaire could be used to assess changes in both medical students' knowledge and attitudes following their education in this area, we decided to proceed with the study. The questionnaire consisted of six questions assessing students' knowledge about hospice: 1) appropriate time to start hospice and palliative care; 2) appropriate applicants for hospice and palliative care; 3) essential knowledge about hospice and palliative care; 4) available occupation for the hospice and palliative care team; 5) typical role of a physician in hospice and palliative care; 6) use of opioid pain control in hospice and palliative care and three questions assessing students' attitude toward hospice care: 1) confidence of ex- planation about the purpose and role of hospice and palliative care; 2) confidence about when they have to advise patients about hospice and palliative care; 3) willingness to have student's future patients consider hospice and palliative care. The questionnaires were administered before and right after the end of the course.

The researcher the study's purpose to each participant before data collection. After providing consent, the participants were then asked to complete the questionnaire in a classroom before the beginning of the hospice and palliative care course and immediately after it finished. On average, it took under 10 minutes to complete the questionnaire, and no issues were identified regarding participants' understanding of the questionnaire items.

The Institutional Review Board of the Kosin University Gospel Hospital approved the survey protocol, with the requirement that participants would read a description of the study and provide consent before completing the questionnaire (IRB Number KUGH 2016-08-006). All study protocols complied with the Declaration of Helsinki.

\section{Curriculum}

The hospice and palliative care curriculum was first introduced for fourth-year medical students in 2010 as a part of an integrative medicine course. Originally, the curriculum consisted of eight hours of lecture on end of life and palliative care. By 2014, this course was expanded to 16 hours, and integrated education for hospice and palliative medicine was provided to students by the School of Medicine at Kosin University. Students received a total of 16 hours of hospice and palliative medicine education from June 27 to July 6, 2016. The course consisted of lectures, interviews, presentations, discussions, case-based learning, and field learning.

Hospice teaching team were composed of five health care professionals; one radio-oncologist, one hospice-specialized family physician, one nursing professor, one social worker one experienced hospice volunteer. Every professional was palliative and hospice care expert and care experiences were ranged from 5 years to 20 years.

The course provided education about the necessity of hospice and palliative medicine. The module largely divided into onehour segments, one for each of the following topics or activi- 
ties: an introduction to complementary medicine explaining needs and general concept of hospice care, the basic concepts and composition of hospice care, pain management for hospice patients including appropriate use of opioids and other analgesics, the management of the digestive and respiratory systems of hospice patients with the review of clinical cases, the management of neurologic, psychiatric, and symptoms including how to screen and deliver appropriate care with the symptoms, patient management at the time of death, home care for hospice patients and institutional challenges to implement the care system in South Korea, social issues and policies regarding palliative and hospice care, working as hospice volunteers focusing on personal experience of hospice volunteer who had worked more than 15 years, and a course summary and test assessing students' achievement in knowledge of palliative and hospice care. Most of the courses in classroom were case-based and one-way teaching. Four hours were devoted to gaining hospice and palliative medical ward experience as shown in Table 1. Rotation in ward was composed of morning rounding, care meeting, discussion about the each patients' care issues, extended care team meeting and evening rounding, and every educational activities was conducted under the supervision of the hospice-specialized family physician.

\section{Statistical analysis}

The collected data were analyzed using SPSS Win 23.0 (LCC, Kaysville, UT, USA), with the significance level set as $\mathrm{P} \leq 0.05$. Descriptive statistics on participant characteristics were obtained using frequencies and averages. Differences in hospice and palliative care knowledge and attitudes before and after the course were assessed through McNemar and Wilcoxon tests.

\section{RESULTS}

The participants' characteristics are summarized in Table 2. There were 58 men and 18 women; 66.6\% ( $n=52)$ were younger than 25 years. Regarding religion, $47.4 \%(n=36)$ of participants identified as atheists and $31.6 \%(n=24)$ as Christians. In addition, $31.6 \%(n=24)$ had experienced a family member passing away owing to terminal illness. Only four of the students (5.3\%) had experienced a family member receiving hospice and palliative care due to a terminal illness. Most students (97.4\%) had heard about hospice and palliative care before attending the course. The most common method by which students had learned about hospice and palliative

Table 1. Curriculum.

\begin{tabular}{|c|c|c|c|}
\hline Date & Course & Contents & Time (hrs) \\
\hline \multirow[t]{4}{*}{ June 27, 2016} & The necessity of hospice and palliative medicine & $\begin{array}{l}\text { An introduction to complementary medicine explaining needs and } \\
\text { general concept of hospice care }\end{array}$ & 1 \\
\hline & Introduction to complementary medicine & & 1 \\
\hline & Basic concepts and composition of hospice & The basic concepts and composition of hospice care & 1 \\
\hline & Management of pain in hospice patients & $\begin{array}{l}\text { Pain management for hospice patients including appropriate use of } \\
\text { opioids and other analgesics }\end{array}$ & 1 \\
\hline \multirow[t]{4}{*}{ June 29, 2016} & $\begin{array}{l}\text { Management of the digestive system and } \\
\text { respiratory care in hospice patients }\end{array}$ & $\begin{array}{l}\text { Management of the digestive and respiratory systems of hospice } \\
\text { patients with the review of clinical cases }\end{array}$ & 1 \\
\hline & Management of other symptoms & $\begin{array}{l}\text { Management of neurologic, psychiatric, and symptoms including how } \\
\text { to screen and deliver appropriate care with the symptoms }\end{array}$ & 1 \\
\hline & Patient management at the time of death & How to deliver appropriate care for patents at the time of death & 1 \\
\hline & Home care for hospice patients & $\begin{array}{l}\text { Home care for hospice patients and institutional challenges to } \\
\text { implement the care system in South Korea }\end{array}$ & 1 \\
\hline \multirow[t]{4}{*}{ July 4, 2016} & Social interest and policies regarding hospice & Social issues and policies regarding palliative and hospice care & 1 \\
\hline & Hospice volunteers & $\begin{array}{l}\text { Working as hospice volunteers focusing on personal experience of } \\
\text { hospice volunteer who had worked more than } 15 \text { years }\end{array}$ & 1 \\
\hline & Summary & & 1 \\
\hline & Test & & 1 \\
\hline \multirow[t]{2}{*}{ July 6, 2016} & Hospice and palliative medical ward experience & Bedside experience working with hospice team members & 4 \\
\hline & & & Total 16 \\
\hline
\end{tabular}


care was "during medical school (lectures, PK training, etc.)" (89.5\%), followed by "mass media" (35.5\%), "the internet" (21.1\%), "family or acquaintances" (14.5\%), and, finally, "lit-

Table 2. General Characteristics of the Study Participants.

\begin{tabular}{|c|c|}
\hline General characteristics of the study participants & $\mathrm{N}(\%)$ \\
\hline \multicolumn{2}{|l|}{ Gender } \\
\hline Male & $58(76.3)$ \\
\hline Female & $18(23.7)$ \\
\hline \multicolumn{2}{|l|}{ Age (yr) } \\
\hline 25 or younger & $52(66.6)$ \\
\hline Older than 25 & $24(33.4)$ \\
\hline \multicolumn{2}{|l|}{ Religion } \\
\hline Protestant & $24(31.6)$ \\
\hline Catholic & $8(10.5)$ \\
\hline Buddhist & $7(9.2)$ \\
\hline Others & $1(1.3)$ \\
\hline None & $36(47.4)$ \\
\hline \multicolumn{2}{|l|}{$\begin{array}{l}\text { Experience of a family member passing away from terminal } \\
\text { cancer or other illness }\end{array}$} \\
\hline Yes & $24(31.6)$ \\
\hline No & $52(68.4)$ \\
\hline \multicolumn{2}{|l|}{$\begin{array}{l}\text { Experience of a family member receiving hospice and } \\
\text { palliative care because of terminal cancer or other illness }\end{array}$} \\
\hline Yes & $4(5.3)$ \\
\hline No & $72(94.7)$ \\
\hline \multicolumn{2}{|l|}{ "I have heard about hospice and palliative care." } \\
\hline Yes & $74(97.4)$ \\
\hline No & $2(2.6)$ \\
\hline \multicolumn{2}{|l|}{$\begin{array}{l}\text { “I have heard of hospice and palliative care from...” (Multiple } \\
\text { responses possible) }\end{array}$} \\
\hline Family or acquaintance & $11(14.5)$ \\
\hline Internet & $16(21.1)$ \\
\hline Literature & $6(7.9)$ \\
\hline Mass media (TV, radio, etc.) & $27(35.5)$ \\
\hline During medical school (lecture, bedside training, etc.) & $68(89.5)$ \\
\hline
\end{tabular}

erature" (7.9\%).

Regarding the question about the appropriate time to begin hospice care, $71.1 \%$ (pre, $n=54$ ) and $76.3 \%$ (post, $n=58$; $\mathrm{P}=0.541)$ of the participants selected "when surgery, radiotherapy, and chemotherapy are no longer effective treatments for cancer patients" to answer this question. Participants selected an average of 3.67 correct responses to questions regarding appropriate patients for hospice and palliative care before the course and 4.01 correct responses after the course $(\mathrm{P}=0.025)$. Participants selected "yes" an average of 4.62 (pre) and 4.64 (post) times to the five statements about their general familiarity with hospice before and after the course $(\mathrm{P}=0.635)$ (Table 3).

Of the possible correct responses participants selected an average of 5.39 correct responses pre-course and 5.71 correct responses post-course to the question concerning occupations involved in hospice and palliative care teams $(\mathrm{P}=0.015)$. There was no significant pre- and post-course difference between the average number of correct answers provided for the question on the typical roles of physicians in hospice and palliative care (6.82 and 6.87, respectively). The most notable difference in the average number of correct answers provided pre- and post-course was seen for the question on opioid utilization for pain control (3.50 and 5.32, respectively; $\mathrm{P} \leq 0.001$ ). As shown in Table 3, there were no other significant differences before and after the course.

Before the course, 17 (22.4\%) students expressed positive feedback regarding learning about the purposes and roles of hospice and palliative care, compared to 65 (85.6\%) students after the course $(\mathrm{P} \leq 0.001)$. Participants became more confi-

Table 3. Comparison of Knowledge on Hospice and Palliative Care before and after the Class.

\begin{tabular}{lcc}
\hline & Before class & After class \\
\cline { 2 - 3 } 1. Appropriate time to start hospice and palliative care & $\mathrm{N*}(\%)$ & $\mathrm{N}^{*}(\%)$ \\
\hline
\end{tabular}

*N (\%) is the number of students who selected the right answer, ${ }^{\dagger} \mathrm{P}$-value was obtained by McNemar's test, ${ }^{\dagger} \mathrm{N}(\%)$ is the number of right answers which the students selected, ${ }^{\S} \mathrm{P}$-value was obtained by Wilcoxon test. 
Table 4. Comparison of Positive Attitude on Hospice and Palliative Care before and after the Class.

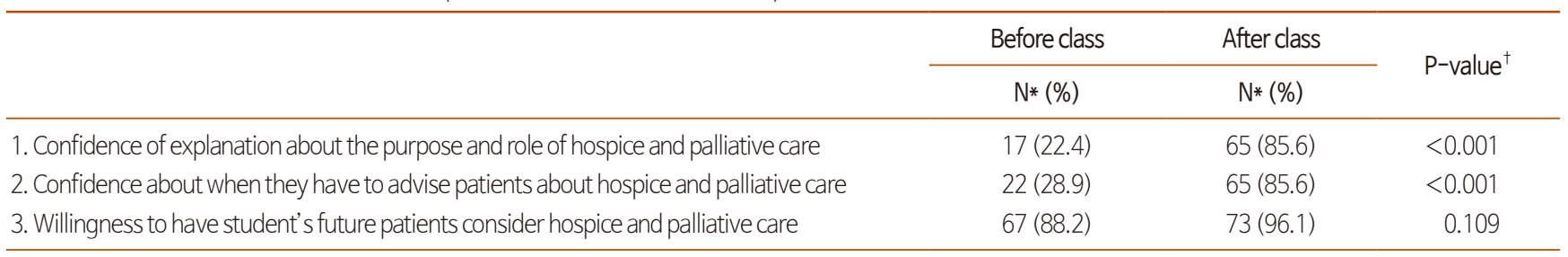

*N (\%) is the number of students who answered "Strongly agree" or "Agree", ${ }^{\dagger} \mathrm{P}$-value was obtained by McNemar's test.

dent in their understanding of the appropriate time to advocate that patients pursue hospice and palliative care $(28.9 \%$ to $85.6 \% ; \mathrm{P} \leq 0.001)$. There were no statistically significant differences in participants' willingness to consider hospice and palliative care for their future patients (Table 4).

\section{DISCUSSION}

This study found positive changes in medical students' knowledge and attitudes toward hospice and palliative medicine following an integrated educational course. Medical students who participated in the study were provided comprehensive educational course regarding hospice and end-of life care. Previously developed hospice curriculums were composed of either discussing hospice cases in the classroom (11) or one or two week hospice rotation in ward (12). However, because this course was consisted of both medical knowledge on hospice and clinical experience in the hospice ward where medical students could interact with hospice patients and care team members, trainees were likely to gain broad perspective on hospice care. Moreover, our curriculum included not only medical professional but other team member such as experienced hospice volunteer and social worker as lecturers, so that medical students had an opportunity to understand how to work effectively with non-medical personals in hospice care.

Several studies have reported that integrated palliative and end-of-life care education have positive impacts on various medical professionals' attitudes toward hospice care. In one study, both the number of instances in which residents in internal medicine engaged in palliative care and residents' total years of clinical experience positively affected their overall perceived competence (11). For participants in the present study, participating in the course improved both perceived competence and knowledge levels regarding palliative care. A study conducted among medical graduates found that mandatory training in palliative and end-of-life care effectively equipped them with strong skills in these areas (12). In another study, students who completed hospice rotations during their clinical years reported that end-of-life care was the most important area they had studied (13). Graduates exposed to end-of-lifecare broadened their knowledge in medicine, expanded their assumptions about suffering, and experienced greater clarity regarding the roles of healthcare professionals (13).

The number of correct answers provided for questions regarding appropriate patients for hospice and palliative care significantly increased following the educational sessions. Students were presented with several clinical cases and asked whether the patient, in each case, should be considered as a candidate for hospice and palliative care. Presented cases included several types of patients seen frequently in physicians' practices, indicating that students can accurately identify appropriate patients in actual medical practice.

Identifying eligible patients for end-of-life care and appropriately referring them to hospice and palliative services is important prior to the patients' imminent death. Laws regarding medical decision-making for patients in hospice and palliative care also emphasize the importance of referral timing (14). Identifying appropriate patients for hospice and palliative care is a crucial skill for future medical professionals to gain to provide optimal care.

The fact that $89.5 \%$ of the participants indicated that they had heard of hospice and palliative care through their universities highlights the importance of medical school education in providing proper awareness and promoting positive attitudes about these medical services.

The number of correct answers to questions on available occupations in hospice and palliative care teams also increased overall. The ultimate goal of hospice and palliative care is to 
increase patients' quality of life (rather than to attempt lifesaving treatments) through comprehensive and continuous care for patients whose death is predicted within six months. Therefore, a team-centered approach is important in achieving this goal. However, very little high-quality evidence suggests that end-of-life communication training may improve healthcare professionals' self-efficacy, knowledge, and end-of-life communication scores compared to more traditional teaching methods (15). Further studies are recommended to provide increased data and more detailed analysis on this issue.

In this study, the greatest change was observed in students' knowledge on the usage of opioid analgesics for patients with severe pain in hospice and palliative care. Students from the Alpert Medical School who had completed their hospice rotations were asked to rate how prepared they felt to complete common symptom management tasks, rather than simply whether they possessed the required procedural knowledge (16). Almost a quarter of graduating medical students did not feel prepared to palliate common symptoms, including pain, nausea, shortness of breath, and anxiety (16). Although patients in hospice and palliative care wards reported that they largely expected their pain to be controlled after being admitted (17), their pain was apparently poorly controlled due to inadequate opioid analgesic utilization (18). In addition, according to a report by the International Narcotics Control Board, the use of opioid analgesics in Korea is very low relative to other countries (19). In Korea, around 76,000 cancer patients die each year, with 80 to $90 \%$ of terminal patients suffering from pain. More than half of these patients do not receive appropriate symptom management, including pain control (20). Thus, hospice and palliative care classes are important in teaching medical students the proper use and side effects of opioid analgesics.

Medical students expressed positive feedback concerning learning about the goals and roles of hospice and palliative care following the course. We also observed that the course was helpful in increasing participants' knowledge of hospice and palliative care, which increased by $63.2 \%$ after the course. According to Kim's (2012) study, after reflecting on the meaning of death within end-of-life care education, most students recognized the need for this type of medical service. Kim concluded that this experience effected remarkable changes in students' awareness and attitudes toward end-of-life patients (21).

Students became more confident in advising patients about hospice and palliative care. Hospice and palliative care are usually intended for patients anticipated to die within six months. Encouraging these forms of care at the appropriate time can help both patients and caregivers maintain their overall quality of life and prepare for the patient's death. Furthermore, increased confidence of explanation about the purpose and role of hospice and palliative care among medical students is also likely to contribute to qualified delivery of hospice care for future patients. This change in perceptual confidence regarding appropriate explanation for hospice care might ease the hesitation to recommend hospice care for terminal patients (22).

Regarding their willingness to encourage future patients to consider hospice and palliative care, there were no significant differences found in participants pre- and post-course responses. This is likely because the number of students who initially answered "yes" was already high and because the total number of participants in this study was small. In addition, this item might have been affected by the fact that $97.4 \%$ of the students were already familiar with hospice and palliative care before attending the course.

Participants' responses to items asking them to identify basic concepts concerning the role of physicians in hospice and palliative care did not significantly change following the integrated course. However, the number of correct or positive responses provided by students to questions concerning the role of hospice and palliative care and participants' willingness to recommend it to their future patients did increase. Although the course was positively associated with increased knowledge about hospice care, attitudinal changes regarding end-of-life care were insignificant, particularly in whether participants would recommend hospice care to their future patients. One possible explanation for this finding is the course employed a one-directional educational approach rather than a bidirectional approach such as problem-based learning, which is a well-known educational tool for changing students' attitude (23). Thus, future research is needed to explore the differences in knowledge gains and attitudinal changes realized through different educational approaches. 
This study has several limitations. First, although the course included four hours of hospice and palliative medical ward experience, no specific question addressed how this affected students' knowledge and attitudes. In one study, students who reported personal or professional experience with death demonstrated more positive attitudes, as well as higher knowledge scores, than those who did not (24). Second, the contents of the questionnaire did not change between the first and second survey, meaning that a learning effect could have affected the results of this study. Third, as this study was conducted with a small sample of university students, there are some limitations regarding the generalizability of the results to other settings and population. Fourth, because we only analyzed changes in attitudes and knowledge after hospice and palliative care training, the effects of education on practice could not be evaluated. Fifth, the questionnaire was originally developed to assess students' satisfaction about the course, data on the validity and reliability of questionnaire is limited. Finally, because most of the questions concerned knowledge about hospice, attitudes about hospice could be assessed in a limited manner. To address this limitation, further studies must ask specific questions concerning medical students' perceptions toward hospice, such as "Would you choose to use hospice when you or your family members are in terminal conditions?".

Hospice and palliative care education is positively associated with better understandings and attitudes toward end-of-life care among medical students. The development of emotionally supportive settings in which to teach students about hospice and palliative care should be considered. In future, it will be necessary to expand upon this study by including a larger sample of medical school students and to determine whether the course is helpful in practice.

\section{요약}

목적: 높은 수준의 호스피스 및 완화의료 교육은 한국 의과대학 교육 과정에 필요하다. 하지만 이와 연관된 연구는 많지 않은 실정이며 이 에 본 연구는 호스피스와 완화의료 교육 과정을 마친 의과 대학생의 호스피스와 완화의료에 대한 인지 및 태도 변화를 연구하기 위해 수 행 되었다. 또한 의과대학의 기본 교육 과정 안에서 호스피스 교육 과정의 역할에 대해서도 탐구하고자 한다.

방법: 호스피스와 완화의학에 대한 통합적인 교육과정을 마친 총 76 명의 의학과 4 학년 학생이 자기 기입 형태의 설문조사에 참여 하였 다. 교육 과정을 마친 후 수업 전과 비교하여 수업 후의 후의 호스피 스 및 완화의료에 대한 지식과 태도를 조사하였다.

결과: 교육 과정을 이수한 이후 가장 큰 변화는 호스피스 및 완화의 료 세팅에서 적절한 마약성 진통제를 사용할 수 있는가 하는 부분에 서 나타났다(3.50점 vs 5.32 점; $\mathrm{P} \leq 0.001$ ). 수업 전과 비교하여 수 업 이후 호스피스와 완화의료에 대한 태도를 나타내는 질문인 "나는 호스피스와 완화의료의 목표와 역할을 바르게 알고 있다" 고 답한 학 생은 17명(22.4\%)에서 65명(85.6\%)으로 증가하였다. 또한 "예비의 사로서 나는 호스피스와 완화의료의 바른 적용 시점을 알고 있다”고 답한 학생은 수업 전의 22 명(28.9\%)과 비교하여 65 명(85.6\%)으로 증가하였다.

결론: 통합적인 호스피스 완화의료 교육과정은 의과 대학생의 호스 피스 및 완화의료에 대한 인식과 태도를 긍정적인 방향으로 변화시 킬 수 있다.

중심단어: 호스피스, 완화의료, 인지, 태도, 의학교육

\section{REFERENCES}

1. South-Paul JE, Matheny SC, Lewis EL. Current diagnosis \& treatment in family medicine [Internet]. 4th ed. New York (NY): Lange Medical Books/McGraw-Hill; c2015. Chapter 67, Hospice \& palliative medicine; [cited 2018 Oct 15]. Available from: http://accessmedicine.mhmedical.com/content.aspx? bookid=1415\&sectionid=77062172.

2. Gibbins J, Mccoubrie R, Forbes K. Why are newly qualified doctors unprepared to care for patients at the end of life? Med Educ 2011;45:38999.

3. General Medical Council. Tomorrow's doctors: outcomes and standards for undergraduate medical education. London:GMC;2009. p.1-108.

4. Chang HH, Hu WY, Tsai SS, Yao CA, Chen CY, Chiu TY. Reflections on an end-of-life care course for preclinical medical students. J Formos Med Assoc [Internet]. 2009;108:636-43 [cited 2018 Oct 15]. Available from: http://dx.doi.org/10.1016/S0929-6646(09)60384-3.

5. Hesselink BA, Pasman HR, van der Wal G, Soethout MB, Onwuteaka-Philipsen BD. Education on end-of-life care in the medical curriculum: students' opinions and knowledge. J Palliat Med 2010;13:381-7. 
6. Dickinson GE. Thirty-five years of end-of-life issues in US medical schools. Am J Hosp Palliat Med 2011;28:412-7.

7. Hong YS. Past, present and future of hospice in Korea. J Korean Med Assoc 2008;51:509-16.

8. Kang J, Kim DY, Shin D, Kim SY, Lee SN. A survey on the certification and curriculum development for hospice and palliative care professionals. Korean J Hosp Palliat Care 2010;13:32-40.

9. Kim SH, Choi YS, Shin SW, Chong MK, Lee SN, Lee SW, et al. Development of Education Program for physicians Based on the 2004 Hospice Palliative Model Project for Terminal Cancer. Korean J Hosp Palliat Care 2006;9:67-76.

10. Kang J, Shin D, Hwang E, Kim H, Ahn S, Yoo Y. Hospice education among hospice professionals and its regional variations in Korea-Outcomes from a 2008 Hospice Palliative Care Institutions Support Project. Korean J Hosp Palliat Care 2009;12:132-8.

11. Mulder SF, Bleijenberg G, Verhagen SC, Stuyt PM, Schijven MP, Tack CJ. Improved competence after a palliative care course for internal medicine residents. Palliat Med [Internet]. 2009;23:360-8. [cited 2018 Oct 15]. Available from: http://ovidsp.ovid.com/ovidweb.cgi? T=JS \& PAGE $=$ reference \&D=emed12\&NEWS $=$ N\&AN=354616363.

12. Ross DD, Shpritz D, Hull MM, Goloubeva O. Long-term evaluation of required coursework in palliative and end-of-life care for medical students. J Palliat Med 2005;8:962-74.

13. Jacoby LH, Beehler CJ, Balint JA. The impact of a clinical rotation in hospice: medical students' perspectives. J Palliat Med 2011;14:59-64.

14. The National Law Information Center [Internet]. Act on Decisions on Life-Sustaining Treatment for Patients in Hospice and Palliative Care or at the End of Life. Sejong: Korea Ministry of Government Legislation; c1997-2019. [cited 2018 Oct 15]. Available from: http://www.law. go.kr/LSW/LInfoP.do? lsiSeq=205656\&efYd=20190328\#0000.

15. Chung HO, Oczkowski SJ, Hanvey L, Mbuagbaw L, You JJ. Educational interventions to train healthcare professionals in end-of-life communication: a systematic review and meta-analysis. BMC Med Educ [Internet]. 2016;16:131.

16. DiBiasio E. Palliative and End-of-Life Care Education Among Alpert Medical School Students. RI Med J 2016;99:20-5.

17. Oh S, Cho W, Kim J, Lee H, Lee D, Shim J. Attitudes of medical students' toward end-of-life care decision-making. Korean J Hosp Palliat Care 2008;11:140-6.

18. Pargeon KL, Hailey BJ. Barriers to effective cancer pain management: a review of the literature. J Pain Symptom Manage 1999;18:358-68.

19. International Narcotics Control Board. Report of the International Narcotics Control Board for 2008 [Internet]. New York : United Nations; 2009. [cited 2018 Oct 15]. Available from: https://www.incb.org/incb/en/publications/annual-reports/annual-report.htmll.

20. Ministry of Health and Welfare. Ministry of Health and Welfare's white paper 2015 [Internet]. Seoul; 2016. [cited 2018 Oct 15]. Available from: http://www.mohw.go.kr/react/modules/download.jsp?BOARD_ID=3700\&CONT_SEQ=292949\&FILE_SEQ=213060.

21. Kim HK, Nam E, Lee KE, Lee SN. Awareness and attitude change after end-of-life care education for medical students. Korean J Hosp Palliat Care 2012;13:30-5.

22. McGorty EK, Bornstein BH. Barriers to physicians' decisions to discuss hospice: insights gained from the United States hospice model. J Eval Clin Prac 2003;9:363-72.

23. Ferreira MM, Trudel AR. The impact of Problem Based Learning (PBL) on student attitudes toward tcience, troblem-Solving skills, and sense of Community in the Classroom. J Classroom Interaction 2012;47:23-30.

24. Anderson WG, Williams JE, Bost JE, Barnard D. Exposure to death is associated with positive attitudes and higher knowledge about end-oflife care in graduating medical students. J Palliat Med 2008;11:1227-33. 